\title{
A Comparative Study between Rhodes Grass (Chloris gayana Kunth) with Local Grass Forages
}

\author{
Ahmed Ali Mohamed Osman ${ }^{1}$, Abdel Aziz Hamid Abdel Aziz 2,*, Faisal Suleiman Hag Babiker ${ }^{2}$ \\ ${ }^{1}$ College of Agricultural Studies, Sudan University for Science and Technology, Khartoum North, Sudan \\ ${ }^{2}$ Faculty of Agricultural Technology and Fish Sciences, Al Neelain University, Khartoum, Sudan \\ *Corresponding Author: azhamid1952@gmail.com
}

Copyright (C) 2014 Horizon Research Publishing All rights reserved.

\begin{abstract}
A field trial was conducted for two successive seasons 2006 - 07 at the experimental farm of Shambat Research Station, Khartoum North to compare the yield of 5 cultivars of Rhodes grass and 2 local grass fodders. A randomized complete block design was used. The first cut for all the entries was taken when the plants reached $50 \%$ flowering. The three subsequent cuts were taken at intervals of 35 days in case of Rhodes where as for Abu sabein and Garawya at $50 \%$ flowering. The forage yield was evaluated across four cuts. The study revealed that Rhodes grass significantly out yielded forage Sorghum cultivars $\mathrm{Abu}$ Sabein and Garawya in all cuts other than the first one. Quality wise the percentages of protein shown by Rhodes grass were comparable if not better than those reported in Abu Sabein or in forage Sorghum in general.
\end{abstract}

Keywords Dry matter yield, Green matter yield

\section{Introduction}

Rhodes grass (Chloris gayana Kunth) is a perennial grass of tropical and subtropical Africa where it remained one of the main $\mathrm{C}_{4}$ forage grasses. Rhodes grass can be used as pasture, hay and ley crop. It is also can be used to stabilize disturbed sites. It is found in open grassland, or in grassland with scattered bush and trees, lake margins or seasonally waterlogged plains up to $2000 \mathrm{~m}$ altitude, rarely higher. (Bogdan, 1969 and 1977).

The natural distribution of Rhodes grass through much of Africa and the extensive sowing and naturalized stands elsewhere demonstrate the wide environmental adaptation of the species as a whole. It also reflects the tremendous intra-specific variation, such that different forms that can exploit different environments, Loch et al (2004). Cameron (1967) is best suited to about $600-1200 \mathrm{~mm}$ rainfall belt. It was reported that Rhodes grass, like other tropical and sub tropical greases, grows best at high temperatures, Murata et al (1965). Skerman and Riveros (1990) stated that Rhodes grass is tolerant of fire, a heavy fire may thin the stand by killing some of the smaller rooted stolon nodes, and also it is not shade tolerant, as it is expected from its origin in open woodland and grassland.

Cameron, (1967), Bogdan, (1969) and Loch (1980) reported that Rhodes grass is adapted to a wide range of soil types and conditions. It grows best on fertile barns, ranging from sandy textured and red volcanic soils to clay loams, but also reasonably tolerant of less fertile and poorly drained conditions. Chippendall (1955) and Bogdan (1958) reported that Rhodes grass is one of the more salt-tolerant $\mathrm{C}_{4}$ forage grasses.

The recent statistics of the Ministry of Agriculture (2006) showed that the area under forage crops represented $80 \%$ of the area cultivated in Khartoum State. This area was almost doubled from (2001) to (2006), from 60.000 to 114513 feddans, ( 1 feddan $=0.42$ hectare). This expansion was due to growing importance forage crops.

The system of forage production adopted in the Sudan is the green chopping system. This system does not allow continuous supply of animal feed. According to the recent statistics, $90 \%$ of the animal wealth in the Sudan relay on natural pastures and crop residues, (N.C.S., 1999). Due to the rising demand of animal products for local consumption and for export, there is a need for better forage cultivars that maintain continuous supply of forages. The dependence on perennial forage crop can secure continuous availability supply of animal feed around the year. Also a forage grass such as Rhodes grass can lend itself for hay making and grassing systems is expected to secure continuous supply of animal feed.

The objective of this study is to evaluate Rhodes grass under Sudan conditions in comparison to two local Sorghum forage cultivars.

\section{Materials and Methods}

A trial was conducted for two successive seasons 2006 2007 at the experimental Farm of Shambat Research Station, Khartoum North, Sudan. Five cultivars of Rhodes grass and two local grass fodders were used. The local grass fodders 
were Abu Sabein (Sorghum bicolor L. Moench), a dual purpose grain-fodder cultivar and Garawya (Sorghum sudanense Piper Stapf.). Rhodes grass cultivars were Fine Cut, Top Cut (from Australia Selected Seed Co. via their agent Ayna'at), Hay Maker, Katambora (from Australian Blue Ribbon Seed Co.) and Katambora Zimbabwi (via KSA).

Sowing was done in plots arranged in a randomized complete block deign with three replications. Plots were of three ridges of $6 \mathrm{~m}$ long and $0.75 \mathrm{~m}$ apart. The seed rates were 10,70 and $120 \mathrm{~kg} / \mathrm{ha}$ for Rhodes grass and Sorghum cultivars respectively. Each plot received $86 \mathrm{~kg} / \mathrm{ha}$ of $\mathrm{P}_{2} \mathrm{O}_{5}$ before sowing and $55 \mathrm{~kg} / \mathrm{ha}$ of nitrogen before the second irrigation. Irrigation intervals were 7-10 days. Weeds were kept minimum using hand tools. The first cut was done at $50 \%$ flowering. After that the cuttings were done at intervals of 35 days in Rhodes grass. In Abu Sabein and Garawya were cut at $50 \%$ flowering. The forage yield was evaluated across four cuts. Observation was recorded on number of days to $50 \%$ flowering, plant height, green matter yield and dry matter yield.

Analysis of variance was carried out for all the observations using the combined data of the two seasons. The cuts were considered as split in time imposed for genotype (main units). The analysis of variance was performed as split plot in time according to Steel and Torrie (1960). The replicates and environment were considered as random effects while the cultivars and cuts as fixed effects. The contrast analysis of Rhodes grass cultivars as a group and the local checks was performed.

\section{Results}

Analysis of variance indicated that highly significant differences were detected between cultivars in forage Yield, Table 1 . The performance across cuts was significant only for green matter yield. The Rhodes grass cultivars significantly out yielded forage Sorghum cultivars in yield averages over the two seasons. The green matter yield of Rhodes grass ranged between 27.0 and $30.3 \mathrm{t} /$ ha obtained by Katambora Zimbabwe and Fine Cut respectively, whereas the respective green matter yield of $\mathrm{Abu}$ Sabein and Garawya were 20.1 and $19.7 \mathrm{t} / \mathrm{ha}$, Table 1. Differences between Rhodes grass cultivars were insignificant. The cultivars kept the same trend in dry matter yield as in green matter.

Analysis of variance also showed that there was highly significant difference detected interaction between cultivars in forage yield. The interaction between cultivars and seasons for green matter yield is not sizable. The performance of cultivars across the four cuts was significant for green matter yield. The interaction between seasons and cultivars with cuts for forage yield was significant. The second order interaction was significant only for green matter yield but it was not sizable.

In the first cut forage Sorghum cultivars showed green matter yield level comparable to most of Rhodes grass whereas the reverse was reported in the subsequent cuts especially the fourth one. The green matter yield level of forage Sorghum cultivars tended to decrease across cut whereas those of Rhode grass were more or less consistent in the second and fourth cuts but showed sizable increase in the third cut. The respective green matter yield of Katambora Zimbabwe across the four cuts were 22.7, 24.6, 25.4 and 35.5 t/ha, Table 2, whereas for Abu Sabein were 33.1, 18.8, 18.7 and $9.9 \mathrm{t} / \mathrm{ha}$. For DMY both Rhodes grass and Abu $70 \mathrm{kept}$ the same trend, Table 3.

Table 1. Average green matter yield and dry matter yield over 4 cuts of 5 Rhodes grass and 2 forage Sorghum cultivars combined over 2 seasons $(2006 / 07)$

\begin{tabular}{|c|c|c|}
\hline Cultivars & Green matter yield & Dry matter yield \\
\hline Abu Sabein & 20.09 & 5.96 \\
\hline Garawya & 19.65 & 5.04 \\
\hline Fine Cut & 30.32 & 7.97 \\
\hline Hay Maker & 29.35 & 7.95 \\
\hline Katambora Australia & 28.40 & 7.74 \\
\hline Katambora Zimbabwe & 29.35 & 6.86 \\
\hline Top Cut & 28.56 & 7.42 \\
\hline Grand mean & 26.29 & 6.85 \\
\hline Significance & $* *$ & 0.35 \\
\hline Standard error & 1.09 & 1.03 \\
\hline L.S.D. (0.05) & 3.19 & 26.4 \\
\hline C.V. \% & 19.3 & $* * 1$ \\
\hline
\end{tabular}

Table 2. Green matter yield of 5 Rhodes grass and 2 forage Sorghum cultivars across 4 cuts combined over 2 seasons (2006/07)

\begin{tabular}{|c|c|c|c|c|c|c|}
\hline \multirow{2}{*}{ Cultivar } & \multicolumn{6}{|c|}{ Green matter yield $\mathrm{t} / \mathrm{ha}$} \\
\hline & Cut 1 & Cut 2 & Cut 3 & Cut 4 & Total & Mean \\
\hline Abu Sabein & 33.06 & 18.76 & 18.67 & 9.87 & 80.36 & 20.09 \\
\hline Garawya & 27.27 & 19.35 & 15.31 & 16.67 & 78.60 & 19.65 \\
\hline Fine Cut & 30.79 & 28.22 & 33.20 & 29.08 & 121.29 & 30.32 \\
\hline Hay Maker & 30.08 & 27.81 & 31.54 & 27.98 & 117.41 & 29.35 \\
\hline $\begin{array}{c}\text { Katambora } \\
\text { Australia }\end{array}$ & 27.59 & 26.52 & 31.49 & 27.98 & 113.58 & 28.40 \\
\hline $\begin{array}{l}\text { Katambora } \\
\text { Zimbabwe }\end{array}$ & 22.66 & 24.56 & 25.42 & 35.45 & 108.09 & 29.35 \\
\hline Top Cut & 25.82 & 27.70 & 31.21 & 29.50 & 114.23 & 28.56 \\
\hline Grand mean & & & & & & 26.29 \\
\hline Significance & & & & & & $* *$ \\
\hline $\begin{array}{c}\text { Standard } \\
\text { error }\end{array}$ & & & & & & 2.10 \\
\hline L.S.D. (0.05) & & & & & & 5.88 \\
\hline C.V. \% & & & & & & 19.3 \\
\hline
\end{tabular}


Table 3. Dry matter yield of 5 Rhodes grass and 2 forage Sorghum cultivars across 4 cuts combined over 2 seasons (2006/07)

\begin{tabular}{|c|c|c|c|c|c|c|}
\hline \multirow{2}{*}{ Cultivar } & \multicolumn{6}{|c|}{ Dry matter yield $\mathrm{t} / \mathrm{ha}$} \\
\hline & Cut 1 & Cut 2 & Cut 3 & Cut 4 & Total & Mean \\
\hline Abu Sabein & 7.94 & 4.57 & 4.82 & 2.52 & 19.85 & 5.96 \\
\hline Garawya & 6.29 & 4.65 & 4.24 & 4.99 & 20.17 & 5.04 \\
\hline Fine Cut & 8.45 & 7.25 & 8.11 & 8.05 & 31.86 & 7.97 \\
\hline Hay Maker & 8.17 & 7.39 & 7.83 & 8.41 & 31.80 & 7.95 \\
\hline $\begin{array}{c}\text { Katambora } \\
\text { Australia }\end{array}$ & 7.33 & 6.83 & 8.54 & 8.25 & 30.95 & 7.74 \\
\hline $\begin{array}{l}\text { Katambora } \\
\text { Zimbabwe }\end{array}$ & 5.00 & 5.85 & 6.62 & 9.98 & 27.45 & 6.86 \\
\hline Top Cut & 6.39 & 6.89 & 8.28 & 8.12 & 29.68 & 7.42 \\
\hline Grand mean & & & & & & 6.85 \\
\hline Significance & & & & & & $* *$ \\
\hline $\begin{array}{c}\text { Standard } \\
\text { error }\end{array}$ & & & & & & 0.73 \\
\hline $\begin{array}{l}\text { L.S.D. } \\
(0.05) \\
\end{array}$ & & & & & & 2.05 \\
\hline C.V. $\%$ & & & & & & 26.4 \\
\hline
\end{tabular}

The contrast of Rhodes grass group vs. forage Sorghum group was highly significant for green matter yield and dry matter yield. The Rhodes grass group out yielded forage Sorghum group in forage yield averaging 28.9 and $19.9 \mathrm{t} / \mathrm{h}$ whereas the respective dry matter yield was 7.59 and $5.0 \mathrm{t} / \mathrm{ha}$, Table 4 .

Table 4. Green matter yield and dry matter yield of Rhodes grass in contrast to Sorghum group averaged over 4 cuts combined over two seasons, (2006-07)

\begin{tabular}{|c|c|c|}
\hline Group & $\begin{array}{c}\text { Green matter yield } \\
(\mathrm{t} / \mathrm{h})\end{array}$ & $\begin{array}{c}\text { Dry matter yield } \\
(\mathrm{t} / \mathrm{h})\end{array}$ \\
\hline Rhodes grass & 28.85 & 7.59 \\
\hline Sorghum & 19.87 & 5.00 \\
\hline Grand mean & 26.29 & 6.85 \\
\hline Significance & $* *$ & $* *$ \\
\hline Standard error & 0.85 & 0.26 \\
\hline C.V. $\%$ & 20.00 & 26.6 \\
\hline
\end{tabular}

Analysis of variance, also, revealed that the interaction of environment with Rhodes grass vs. Sorghum was insignificant, Appendix 2. On the other hand the interaction of Rhodes grass vs. Sorghum with cuts was highly significant.

The contrast of Rhodes grass group vs. forage Sorghum group for green matter yield and dry matter yield in the first cut was insignificant whereas it was significant in the subsequent cuts, Table 5 . The dry matter yield obtained in the first cut was 27.4 and $30.2 \mathrm{t} / \mathrm{ha}$ for Rhodes grass forage Sorghum respectively. The respective performance in the first cut was 30.5 and $13.3 \mathrm{t} / \mathrm{ha}$, Table 5 . The performance of
Rhodes grass group vs. forage Sorghum group for dry matter yield kept the same trend as in green matter yield, Table 6.

Table 5. Green matter yield of Rhodes grass in contrast to Sorghum group across 4 cuts combined over two seasons, (2006/07)

\begin{tabular}{|c|c|c|c|c|c|c|}
\hline \multirow{2}{*}{ Cultivars } & \multicolumn{6}{|c|}{ green matter yield $\mathrm{t} / \mathrm{ha}$} \\
\hline & Cut 1 & Cut 2 & Cut 3 & Cut 4 & Total & Mean \\
\hline Rhodes grass & 27.39 & 26.96 & 30.57 & 30.49 & 115.41 & 28.85 \\
\hline Sorghum & 30.16 & 19.06 & 16.99 & 13.27 & 79.48 & 19.87 \\
\hline Grand mean & & & & & & 26.29 \\
\hline Significance & & & & & & $* *$ \\
\hline $\begin{array}{l}\text { Standard } \\
\text { error }\end{array}$ & & & & & & 1,34 \\
\hline L.S.D. $(0.05)$ & & & & & & 3.98 \\
\hline C.V. \% & & & & & & 20.0 \\
\hline
\end{tabular}

Table 6. Dry matter yield of Rhodes grass in contrast to Sorghum group across 4 cuts combined over two seasons, (2006/07)

\begin{tabular}{|c|c|c|c|c|c|c|}
\hline \multirow{2}{*}{ Cultivars } & \multicolumn{6}{|c|}{ Dry matter yield $\mathrm{t} / \mathrm{ha}$} \\
\hline & Cut 1 & Cut 2 & Cut 3 & Cut 4 & Total & Mean \\
\hline Rhodes grass & 7.07 & 6.84 & 7.88 & 8.56 & 30.35 & 7.59 \\
\hline Sorghum & 7.11 & 4.61 & 4.53 & 3.76 & 20.01 & 5.00 \\
\hline Grand mean & & & & & & 6.85 \\
\hline Significance & & & & & & ** \\
\hline Standard error & & & & & & 0.45 \\
\hline S.D. $(0.05)$ & & & & & & 1.32 \\
\hline C.V. $\%$ & & & & & & 26.6 \\
\hline
\end{tabular}

Table 7. Number of days to $50 \%$ flowering and plant height of 5 Rhodes grass and 2 Sorghum cultivars averaged over 4 cuts based on data combined over 2 seasons $(2006 / 07)$

\begin{tabular}{|c|c|c|}
\hline Cultivars & $\begin{array}{c}\text { Days to 50 \% } \\
\text { flowering }\end{array}$ & Plant height (cm) \\
\hline Abu Sabein & 52 & 106 \\
\hline Garawya & 56 & 105 \\
\hline Fine Cut & 37 & 90 \\
\hline Hay Maker & 40 & 88 \\
\hline Katambora Australia & 36 & 83 \\
\hline Katambora Zimbabwe & 32 & 89 \\
\hline Top Cut & 44 & 81 \\
\hline Grand mean & 42 & 92 \\
\hline Significance & $* *$. & $* *$ \\
\hline Standard error & 1.1 & 4.8 \\
\hline L.S.D. (0.05) & 3.2 & 9.1 \\
\hline C.V. \% & 9.8 & \\
\hline
\end{tabular}


On the average of the four cuts Rhodes grass cultivars were significantly earlier than forage Sorghum cultivars. The number of days to $50 \%$ flowering ranged between 37 to 44 days in Katambora Zimbabwe Top Cut respectively. The former was the earlier among Rhodes grass cultivars and the $\mathrm{w}$ the latest to flower. On other hand Abu Sabein and Garawya took 52 and 56 days respectively to flower, Table 7.

All cultivars took to flower in the first cut with clear trend towards earliness in the subsequent cuts. In the first cut Hay Maker was the earliest in the whole material tested taking around 57 days whereas Top Cut was the grass cultivars flowered earlier than Abu Sabein and Garawya. In the forth cut for example, Rhodes grass cultivars took 18 days (obtained by Katambora Zimbabwe) to 24 days (obtained by both Fine Cut and Hay Maker) to flower, whereas Abu Sabein and Garawya took 46 and 56 days to flower respectively. Table 8 .

Table 8. Number of days to $50 \%$ flowering of 5 Rhodes grass and 2 Sorghum cultivars evaluated across 4 cuts and combined over 2 seasons $(2006 / 07)$

\begin{tabular}{|c|c|c|c|c|c|c|}
\hline \multirow{2}{*}{ Cultivar } & \multicolumn{6}{|c|}{ GMY t/ha } \\
\hline & Cut 1 & Cut 2 & Cut 3 & Cut 4 & Total & Mean \\
\hline Abu Sabein & 66 & 54 & 44 & 46 & 210 & 32.5 \\
\hline Garawya & 67 & 50 & 49 & 56 & 222 & 55.5 \\
\hline Fine Cut & 70 & 30 & 24 & 24 & 148 & 37 \\
\hline Hay Maker & 57 & 32 & 28 & 24 & 141 & 35.3 \\
\hline $\begin{array}{c}\text { Katambora } \\
\text { Australia }\end{array}$ & 80 & 30 & 7 & 19 & 146 & 36.5 \\
\hline $\begin{array}{l}\text { Katambora } \\
\text { Zimbabwe }\end{array}$ & 70 & 23 & 7 & 18 & 128 & 32 \\
\hline Top Cut & 92 & 35 & 26 & 23 & 176 & 44 \\
\hline Grand mean & & & & & & 42 \\
\hline Significance & & & & & & $* *$ \\
\hline $\begin{array}{c}\text { Standard } \\
\text { error }\end{array}$ & & & & & & 1.8 \\
\hline L.S.D. (0.05) & & & & & & 5.1 \\
\hline C.V. \% & & & & & & 9.8 \\
\hline
\end{tabular}

For plant height average of the four cuts, Abu Sabein and Garawya were significantly taller than Rhodes grass cultivars averaging $105 \mathrm{~cm}$ whereas Rhodes grass cultivars ranged from 81 to $90 \mathrm{~cm}$; obtained by Top Cut and Fine Cut respectively. Analysis of variance also showed that differences among cultivars, cuts and their interaction with the environment were highly significant for plant height, Appendix 2.

For the first and second cuts, plant height in Abu Sabein and Garawya were significantly taller than Rhodes grass cultivars. In the first cut Rhodes grass plant height ranged from 83 to $98 \mathrm{~cm}$, obtained by Top Cut and Fine Cut, respectively, whereas the respective values of Abu Sabein and Garawya were 115 and $119 \mathrm{~cm}$, respectively. Plant height in Abu Sabein and Garawya decreased significantly in the third and fourth cuts. In the fourth cut plant height of Rhodes grass cultivars ranged from 82 to $95 \mathrm{~cm}$ obtained by Top Cut and Katambora Zimbabwe, respectively, whereas that of Abu Sabein and Garawya were 107 and $92 \mathrm{~cm}$, respectively, Table 9.

Table 9. Plant height (cm) of 5 Rhodes grass and 2 forage Sorghum cultivars evaluated across 4 cuts and combined over 2 seasons (2006/07)

\begin{tabular}{|c|c|c|c|c|c|c|}
\hline \multirow{2}{*}{ Cultivar } & \multicolumn{6}{|c|}{ GMY t/ha } \\
\hline & Cut 1 & Cut 2 & Cut 3 & Cut 4 & Total & Mean \\
\hline Abu Sabein & 115 & 109 & 94 & 107 & 425 & 106.3 \\
\hline Garawya & 119 & 121 & 90 & 92 & 422 & 105.5 \\
\hline Fine Cut & 98 & 82 & 94 & 86 & 360 & 90.0 \\
\hline Hay Maker & 97 & 81 & 86 & 88 & 352 & 88.0 \\
\hline $\begin{array}{c}\text { Katambora } \\
\text { Australia }\end{array}$ & 87 & 78 & 87 & 80 & 332 & 83.0 \\
\hline $\begin{array}{l}\text { Katambora } \\
\text { Zimbabwe }\end{array}$ & 89 & 80 & 93 & 95 & 357 & 89.3 \\
\hline Top Cut & 83 & 74 & 86 & 82 & 325 & 81.3 \\
\hline Grand mean & & & & & & 92.0 \\
\hline Significance & & & & & & $* *$ \\
\hline Standard error & & & & & & 3.4 \\
\hline L.S.D. (0.05) & & & & & & 9.5 \\
\hline C.V. \% & & & & & & 9.1 \\
\hline
\end{tabular}

\section{Discussion}

Analysis of variance from the combined data of the two seasons indicated that differences between genotypes in forage yield were significant pointing to the existence of genetic variability among the studied genotypes. The study showed that differences Rhodes grass cultivars were insignificant. This may be attributed to the fact that all of the five Rhodes grass cultivars in this study belonged to the diploid type with at least three of them were of the same genetic background. The cultivar Katambora Australia is an ecotype from Katambora Zimbabwe mother population, whereas Fine Cut has been derived from the Australian ecotype, (Loch et al 2004). On the other hand cultivar Top Cut which was bred in Australia from Pioneer group was believed to be had experienced some introgression with some of the Australian ecotypes, (Loch et al 2004).

Due to the insignificant differences among Rhodes grass cultivars, contrast analysis grass as one group was performed vs. Abu Sabein and Garawya as one group. The contrast analysis indicated that Rhodes grass group significantly out yielded forage Sorghum in all cuts other than the first cut.

According to the recent statistic of the Ministry of Agriculture and Animal Wealth of Khartoum State, the traditional cultivar Abu Sabein covered $75 \%$ of the area 
cropped to fodders. Abu 70 though it suits the green chopping system which is dominant in the Sudan, it doesn't lend itself to hay making system under mechanized forage production. The green chopping system has been able in the past to meet the needs for fodder. In view of the rapid pace towards mechanization it is no longer capable of playing that role. This due to that the green chopping system does not employ modern means of production that facilitate wide scale production of forage crops.

Introduction of forage cultivars with attributes better than that of Abu Sabein and at the same time lend itself to mechanized forage production, mechanized hay making system, will help greatly in boosting forage crop production in the Sudan. Rhodes grass being a perennial crop with high yielding capacity, good storability and transportability it is expected to help in bridging the accidental gap in forage production. This gap is a part of the negative features of the green chopping system.

\section{Conclusion}

It can be concluded that Rhodes grass is expected to play a key-role in boosting fodder production in the Sudan through large scale mechanized crop production to secure continuous supply of forage in order to satisfy the increasing demand for forages.

\section{Appendix 1}

Mean square from single ANOVA of 5 Rhodes grass and 2 forage sorghum cultivars for days to $50 \%$ flowering and plant height evaluated up to the forth cut based on combined data over two seasons, (2006-07)

\begin{tabular}{|c|c|c|c|}
\hline \multirow{2}{*}{ Source of variation } & & \multicolumn{2}{|c|}{ Mean Squares } \\
\cline { 2 - 4 } & d.f. & $\begin{array}{c}\text { days to } \\
\text { flowering }\end{array}$ & Plant height \\
\hline Reps & 2 & 3.31 & 58.40 \\
\hline Environment (E) & 1 & 80.11 n.s. & 601.17 n.s. \\
\hline Residual & 2 & 35.31 & 1162.05 \\
\hline Cultivar (V) & 6 & $1824.00^{* *}$ & $2412.65^{* *}$ \\
\hline E x V & 6 & $208.73^{* *}$ & $251.63^{* *}$ \\
\hline Residual & 24 & 28.57 & 65.49 \\
\hline Cut (C) & 3 & $19364.39^{* *}$ & $765.57^{* *}$. \\
\hline E x C & 3 & $2263.29^{* *}$ & $2033.27^{* *}$ \\
\hline V x C & 18 & $576.44^{* *}$ & $415.09^{* *}$ \\
\hline E x V x C & 18 & $79.48^{* *}$ & $314.42^{* *}$ \\
\hline Residual & 84 & 17.16 & 70.62 \\
\hline Total & 167 & & \\
\hline
\end{tabular}

** Significant at $1 \%$ probability level

n.s. Non significant at $5 \%$ probability level

\section{Appendix 2}

Mean square from contrast ANOVA between groups of Rhodes grass and forage sorghum cultivars evaluated up to the forth cut for green matter yield (GMY) and dry matter yield (DMY) based on combined data over two seasons (2006-07)

\begin{tabular}{|c|c|c|c|}
\hline \multirow{2}{*}{ Source of variation } & & \multicolumn{2}{|c|}{ Mean Square } \\
\cline { 2 - 4 } & d.f. & GMY t/h & DMY t/h \\
\hline Rep & 2 & 81.78 & 10.39 \\
\hline Environment & 1 & 831.57 & 35.85 n.s. \\
\hline Residual & 2 & 346.55 & 11.75 \\
\hline Group (G) & 1 & $2766.07^{* *}$ & $229.03^{* *}$ \\
\hline Rhodes vs Sorghum (R & 1 & $2766.07^{* *}$ & $229.03^{* *}$ \\
\hline vs S) & 1 & 194.72 n.s. & 1.37 n.s. \\
\hline E x G & 1 & 194.72 n.s. & 1.37 n.s. \\
\hline E x R vs S & 4 & 86.10 & 7.88 \\
\hline Residual & 3 & 94.85 n.s. & 8.23 n.s. \\
\hline Cut (C) & 3 & $261.54^{* *}$ & 8.80 n.s. \\
\hline E x C & 3 & $652.60^{* *}$ & $35.83^{* *}$ \\
\hline G x C & 3 & $652.60^{* *}$ & $35.83^{* *}$ \\
\hline R vs S x C & 3 & 59.59 n.s. & 7.16 n.s. \\
\hline E x G x C & 3 & 59.59. n.s. & 7.16 n.s. \\
\hline E x R vs S & 24 & 43.28 & 5.50 \\
\hline Residual & 120 & 27.54 & 3.32 \\
\hline Rep x E x G x C & 167 & & \\
\hline Total & & & \\
\hline
\end{tabular}

** Significant at $1 \%$ probability level

n.s. Non significant at $5 \%$ probability level

\section{REFERENCES}

[1] Bogdan, A. V. (1958). Some edaphic vegetational types in Kiboko, Kenya. J. Ecol. 46:115-126.

[2] Bogdan, A. V., (1969). Rhodes grass: Herb Abstract. Common wealth agricultural bureau 39: 1-13.

[3] Bogdan, A. V., (1977). Tropical pastures and fodder plants. Trop. Agric. Ser., Longman Inc. New York pp 77-86.

[4] Cameron, D. G. (1967). Rhodes grass still a major sown pasture. Queensl. Agric. J. 93:528-536.

[5] Chippendall, L. K. A. (1955). Part 1, A guide to the identification of grasses in South Africa. P. 1-527. In D. Meredith (ed.). The grasses and pastures of South Africa. Central News Agency, Cape Town South Africa.

[6] Loch, D. S (1980). Seed assures future of Callide Rhodes. Queensl. Agric J. 106: 183-187.

[7] Loch, D. S.; Norman, F. G. and Willem A. van Neikerk. (2004). Warm season $\left(C_{4}\right)$ grasses. Warm season $C_{4}$ grasses Agronomy Monograph No. 45: 833-871. 
[8] Ministry of Agriculture and Animal Wealth, Statistics, (2006)

[9] Murata, Y., J. Lyama and T. Honma. (1965). Studies on the photosynthesis on forage crops. 4. Influence of air-temperature upon the photosynthesis and respiration of alfalfa and several southern-type forage crops. Proc. Crop Sci. Soc. Jpn. 34:154-158.

[10] N.C.S. (1999) eu.europa.eu/development/icenter/repository/s canned/sd-csp-en.pdf.
[11] Skerman, P. J. and F. Riveros, (1990) Tropical grasses. FAO. Plant Prod. Ser. 23. FAO Rome Pp 283-288.

[12] Steel, R. G. D. and J. H. Torrie, (1960). Principles and procedures of statistics. McGraw-Hill, New York, USA. Pp: 242-245. 